\title{
POLA PERTUMBUHAN BERDASARKAN BERAT DAN TINGGI BADAN SISWA PADA SEKOLAH NEGERI DAN SWASTA DI KOTA DENPASAR, BALI
}

\author{
GROWTH PATTERN BASED ON HEIGHT AND BODY WEIGHT FROM \\ STUDENTS OF GOVERNMENT AND PRIVATE SCHOOL AT DENPASAR, \\ BALI
}

\author{
IDa AYu ManiK DamaYantI ${ }^{\star}$ I KetUt Junitha, IDa Bagus Made SuASKara \\ Program Studi Magister Ilmu Biologi, Program Pascasarjana Universitas Udayana, Bali \\ *Email: idaayumanik27@yahoo.com
}

Diterima 23 September 2016. Disetujui 19 Oktober 2017

\section{INTISARI}

Penelitian untuk mengetahui pola pertumbuhan pada siswa dilakukan di beberapa sekolah dasar dan menengah pertama sekolah negeri dan swasta di kota Denpasar, Provinsi Bali. Sampel ditentukan dengan metode purposive sampling dan pengumpulan data dengan metode cross-sectional. Pola pertumbuhan siswa laki-laki maupun perempuan pada umur 7-15 tahun di sekolah swasta di Denpasar menunjukkan rata-rata lebih besar dibandingkan siswa laki-laki maupun perempuan di sekolah negeri di Denpasar. Persentase kategori underweight lebih tinggi pada siswa-siswa sekolah negeri di Denpasar sedangkan persentase siswa-siswa kategori overweight dan obese lebih tinggi di sekolah swasta nasional plus di Denpasar.

Kata kunci: pola pertumbuhan, ciri antropometri

\begin{abstract}
This research aimedet al. to determine the pattern of growth in several primary schools and secondary public and private schools in Denpasar, Bali Province. Samples were determined using purposive sampling and data were collected by cross-sectional method. The pattern of growth of boys and girls at the age of 7-15 years at private schools in Denpasar shows that the average height and weight were greater than the boys and girls in public schools in Denpasar. The percentage of underweight category was higher at public school in Denpasar and the percentage of children with overweight and obese categories were higher in the private national plus school Denpasar.
\end{abstract}

Keywords: pattern of growth, anthropometric characteristics

\section{PENDAHULUAN}

Pertumbuhan fisik pada siswa mengarah pada pertambahan ukuran tubuh. Puncak pertumbuhan fisik pada siswa setelah umur 0-3 tahun adalah pada masa usia sekolah yaitu 6-12 tahun (Artaria, 2008). Proses pertumbuhan tinggi badan (TB) relatif cepat dan diikuti dengan bertambahnya berat badan (BB). Perubahan pertumbuhan fisik jelas tampak pada saat siswa memasuki usia sekolah, dimana pertumbuhan fisik masa usia sekolah merupakan refleksi keadaan gizi pada masa balita. Faktor yang dapat mempengaruhi pertumbuhan fisik siswa salah satunya status sosial ekonomi keluarga (Latief, 2000).

Penelitian yang dilakukan oleh Artaria (2008) menyebutkan bahwa berat badan antara laki-laki dan perempuan berbeda secara signifikan pada hampir semua kelompok umur, kecuali pada umur 12 dan 13 tahun dimana perempuan mengalami growth spurt. Growth spurt adalah peningkatan kecepatan tubuh yang mengawali periode percepatan pertumbuhan. Growth spurt terjadi dalam waktu yang berbeda pada individu yang berbeda (Purbaningsih et al.., 2011).

Pemantauan pola pertumbuhan siswa dilakukan untuk dijadikan referensi terhadap status kesehatan, gizi, obesitas dan kemajuan selama perawatan terhadap penyakit. Kemiskinan dan kurang gizi yang saling berkaitan akan mempengaruhi tumbuh kembang siswa. Pemantauan tumbuh kembang siswa disertai perbaikan gizi masyarakat akan memberikan dampak positif terhadap tumbuh kembang siswa. Pertumbuhan yang baik dapat mempengaruhi peningkatan produktivitas yang akhirnya akan meningkatkan pendapatan. Di Cina, antara tahun 1975 dan 2010, pertumbuhan siswa-siswa dan remaja meningkat seiring dengan pembangunan ekonomi (Zong et al., 2014).

Pada suatu populasi, pola pertumbuhan dapat diprediksi dengan melakukan pengukuran menggunakan 
metode antropometri terhadap individu-individu antara lain pengukuran postur tubuh pada atlet PPLM (Pusat Pendidikan dan Latihan Mahasiswa) Universitas Negeri Makasar (Hasmyati dan Aprilo, 2014). Pengukuran postur tubuh akan mampu menilai normalitas dan kelainan susunan tulang belakang. Selain itu, di Cina pengukuran terhadap pertumbuhan siswa tidak hanya berguna untuk memantau status gizi

\section{MATERI DAN METODE}

Penelitian ini dilakukan di Kota Denpasar dan pengambilan data dilakukan di beberapa Sekolah Dasar dan Sekolah Menengah Pertama di sekolah negeri dan swasta. Lokasi sekolah dasar dan sekolah menengah pertama negeri yaitu SD 2 Peguyangan serta SMP Negeri 12 di Desa Peguyangan Denpasar sedangkan sekolah swasta nasional plus yaitu SD Denpasar Children Centre dan SMP Petra Berkat dan berlokasi di pusat kota yaitu daerah Renon dan Sidakarya Denpasar. Penelitian dilakukan pada bulan JanuariJuni 2016. Probandus yang digunakan pada penelitian ini adalah 556 siswa yang bersedia menjadi responden dan diberi informed consent serta data diri siswa.

Rancangan penelitian yang digunakan adalah crosssectional yaitu observasi hanya dilakukan satu kali pada setiap subjek dan umur ketika pengukuran mewakili kelas umur dalam suatu populasi. Pada populasi. Pengukuran terhadap postur tubuh juga dapat digunakan untuk mengukur ketidaksetaraan dalam pembangunan manusia di antara populasi yang berbeda (Zong et al., 2014).

Berdasarkan latar belakang tersebut dilakukan penelitian di dua lokasi yang berbeda untuk mengetahui pola pertumbuhan fisik berdasarkan berat dan tinggi badan siswa pada masa SD hingga SMP usia 7-15 tahun.

penelitian ini pola pertumbuhan dilihat berdasarkan berat dan tinggi badan siswa. Pengukuran berat badan menggunakan timbangan digital dan tinggi badan menggunakan alat pengukur tinggi. Tebal lipatan kulit diukur menggunakan skinfold caliper. Pada kuisioner yang diberikan tercantum frekuensi makan serta pendapatan orang tua masing-masing siswa. Indeks massa tubuh (IMT) dihitung dengan membagi antara berat badan $(\mathrm{kg})$ dengan tinggi badan kuadrat $\left(\mathrm{m}^{2}\right)$. Nilai IMT yang diperoleh selanjutnya dinyatakan dalam persentil. Menurut Center for Disease Control and Prevention ,IMT dikategorikan berdasarkan 4 kategori yaitu underweight, normal, overweight dan obese. Untuk mengetahui hubungan antara pendapatan orangtua dengan Indeks Massa Tubuh dilakukan analisis Chisquare.

\section{HASIL}

Penelitian ini dilakukan pada 556 siswa. Pengambilan data dilakukan pada siswa-siswa yang berumur 7-15 tahun, yang berada pada kondisi sehat dan tidak cacat badan maupun mental.

Tabel 1.Distribusi subjek penelitian berdasarkan tempat sekolah, jenis kelamin dan kelompok umur

\begin{tabular}{cccccc}
\hline Kelompok & \multicolumn{2}{c}{ Negeri Denpasar } & \multicolumn{2}{c}{ Swasta Denpasar } & \multirow{2}{*}{ Total } \\
\cline { 2 - 5 } umur(thn) & L & P & L & P & \\
\hline $7-9$ & 67 & 72 & 56 & 54 & \\
$10-12$ & 49 & 47 & 45 & 45 & \\
$13-15$ & 32 & 34 & 35 & 20 & \multirow{2}{*}{556} \\
Total & 148 & 153 & 136 & 119 & \\
\hline
\end{tabular}

Keterangan: L: Laki-laki, P: Perempuan

Pada hasil pengukuran ciri antropometri yang telah dilakukan terdapat perbedaan antara siswa sekolah negeri dengan siswa sekolah swasta Denpasar. Dari seluruh hasil pengukuran tubuh diketahui siswa-siswa di sekolah negeri memiliki rerata berat badan, tinggi

\section{Berat badan}

Rerata berat badan siswa laki-laki di sekolah negeri di Denpasar untuk kelompok umur 7-9 tahun; 10-12 tahun dan 13-15 tahun berturut-turut 25; 37,8 dan 53,8 $\mathrm{kg}$, sedangkan berat siswa perempuan di sekolah negeri di Denpasar untuk kelompok umur yang sama yaitu 25,$3 ; 36,8$ dan $47 \mathrm{~kg}$. Rerata berat badan siswa badan, tebal lipatan kulit (tricep, infrascapula dan suprailiaca) dan IMT yang lebih rendah dibandingkan siswa-siswa di sekolah swasta Denpasar pada semua kelompok umur.

laki-laki di sekolah Swasta di Denpasar untuk kelompok umur 7-9 tahun; 10-12 tahun dan 13-15 tahun berturutturut 31,5; 45,9 dan 54,1 kg.siswa perempuan di sekolah Swasta di Denpasar untuk berat badan kelompok umur yang sama yaitu 28,$4 ; 41,8$ dan $53,2 \mathrm{~kg}$. 


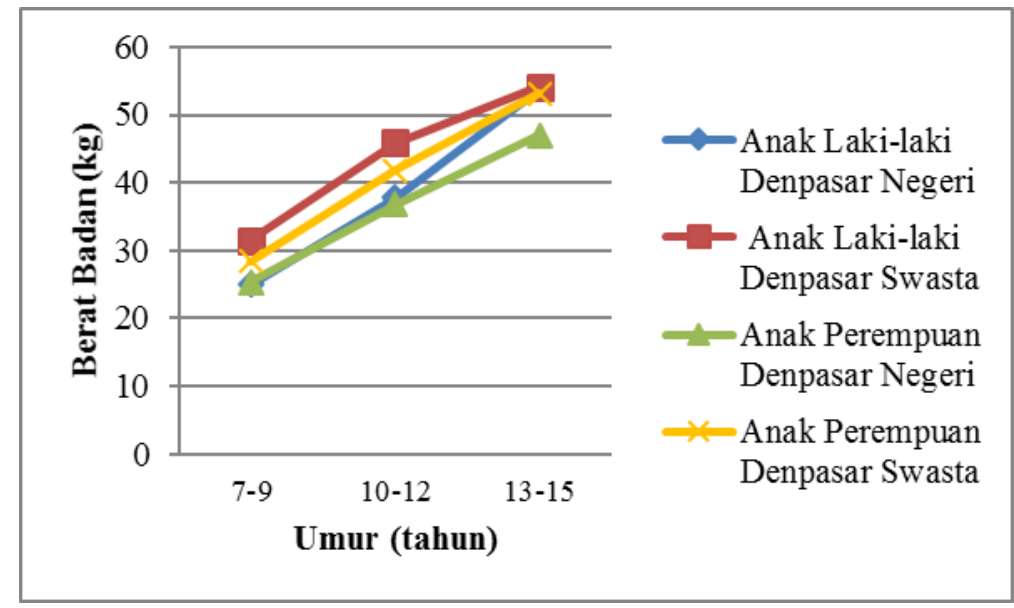

Gambar 1. Berat badan siswa-siswa sekolah negeri dan swasta di Denpasar

\section{Tinggi badan}

Rerata tinggi badan siswa laki-laki negeri di Denpasar untuk kelompok umur 7-9 tahun; 10-12 tahun dan 13-15 tahun berturut-turut 122,3; 139,8 dan $163,3 \mathrm{~cm}$, sedangkan siswa laki-laki di swasta Denpasar untuk kelompok umur 7-9 tahun; 10-12 tahun dan 13-15 tahun berturut-turut 130,$23 ; 146,56$ dan $163,37 \mathrm{~cm}$.
Rerata tinggi badan siswa perempuan di sekolah negeri di Denpasar untuk kelompok umur yang sama yaitu 124,6; 143,8 dan $155 \mathrm{~cm}$, sedangkan tinggi siswa perempuan pada sekolah swasta di Denpasar untuk kelompok umur yang sama yaitu 124,9; 148,5 dan 160,7 cm.

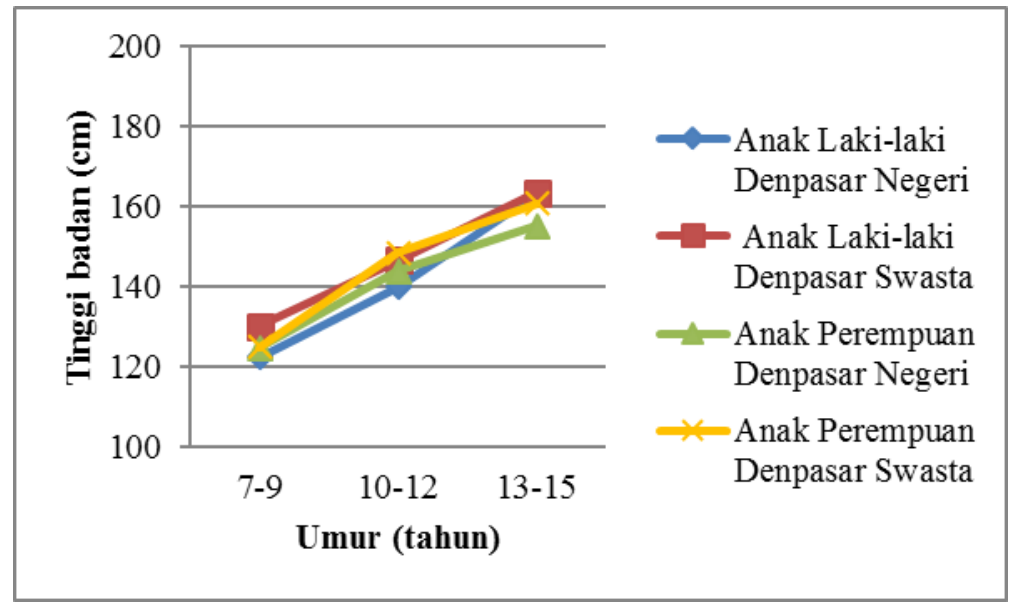

Gambar 2. Tinggi badan siswa-siswa sekolah swasta dan negeri Denpasar

\section{Tebal lipatan kulit triceps}

Rerata tebal lipatan kulit triceps siswa laki-laki di sekolah negeri di Denpasar untuk kelompok umur 7-9 tahun; 10-12 dan 13-15 berturut-turut 10,8; 8,6 dan 9,1 $\mathrm{mm}$, sedangkan pada siswa laki-laki di sekolah swasta untuk kelompok umur yang sama berturut-turut 13,3;
14,6 dan 12,3 mm. Siswa-siswa perempuan pada sekolah negeri di Denpasar untuk ukuran tebal lipatan kulit tricep kelompok umur yang sama yaitu 11,3; 9,3 dan 11,5 mm, sedangkan siswa perempuan di sekolah swasta untuk kelompok umur yang sama yaitu 13; 13,1 dan 14,5 mm. 


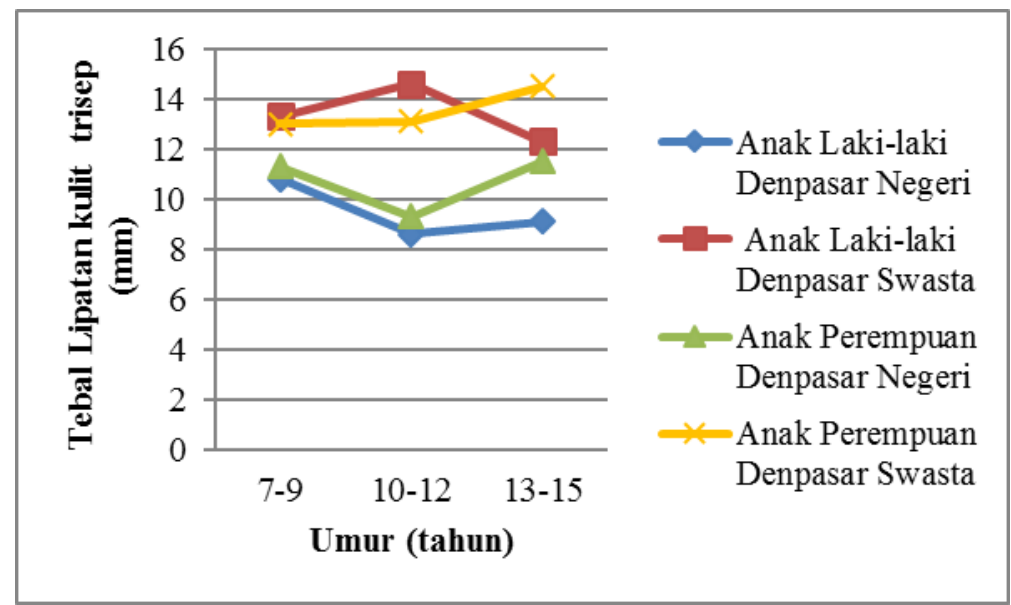

Gambar 3. Tebal lipatan kulit trisep siswa-siswa sekolah swasta dan negeri Denpasar

\section{Tebal lipatan kulit infrascapula}

Pada rerata tebal lipatan kulit infrascapula siswa laki-laki di sekolah negeri di Denpasar untuk kelompok umur 7-9; 10-12 dan 13-15 berturut-turut 8,5; 8,5 dan 9,1 mm, sedangkan pada siswa laki-laki di sekolah swasta untuk kelompok umur 7-9; 10-12 dan 13-15 berturut-turut 11,$3 ; 12,4$ dan $12,2 \mathrm{~mm}$. Siswa-siswa perempuan di sekolah negeri di Denpasar untuk ukuran tebal lipatan kulit infrascapula kelompok umur yang sama yaitu 8,9; 9,1 dan $11 \mathrm{~mm}$, sedangkan siswa perempuan di sekolah swasta untuk kelompok umur yang sama yaitu 11,1; 11,7 dan 15,3 mm.

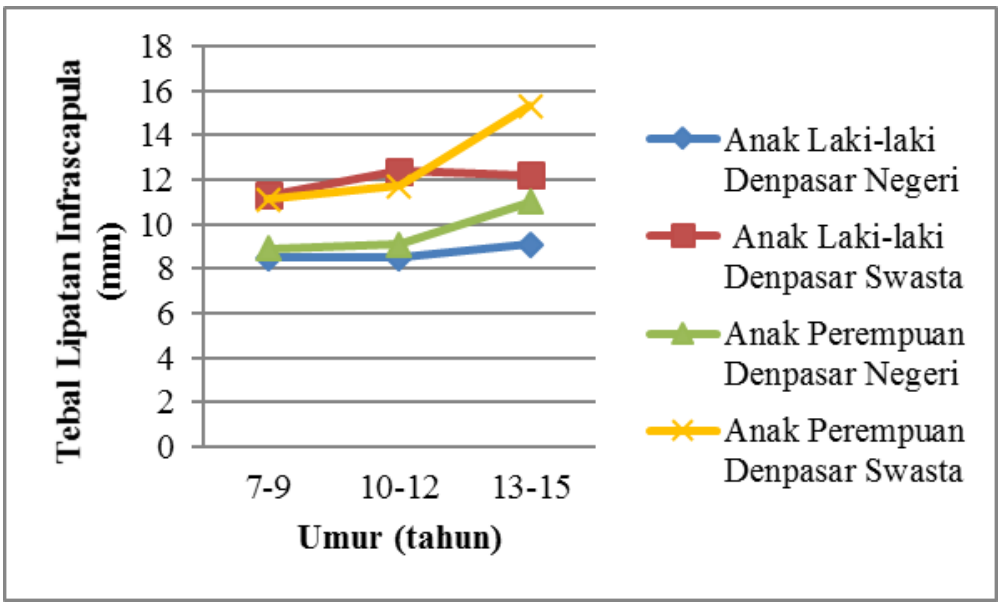

Gambar 4. Tebal lipatan kulit infrascapula siswa-siswa sekolah swasta dan negeri Denpasar

\section{Tebal lipatan kulit suprailiaca}

Pada rerata tebal lipatan kulit suprailiaca siswa lakilaki di sekolah negeri di Denpasar untuk kelompok umur 7-9; 10-12 dan 13-15 berturut-turut 9,3; 8,9 dan 10,7 mm, sedangkan pada siswa laki-laki di sekolah swasta untuk kelompok umur 7-9; 10-12 dan 13-15 berturut-turut 11,$5 ; 13,5$ dan $13,4 \mathrm{~mm}$. Siswa-siswa perempuan di sekolah negeri Denpasar untuk ukuran tebal lipatan kulit suprailiaca kelompok umur yang sama yaitu 9,3; 9,3 dan 11,8 mm, sedangkan siswa perempuan di sekolah swasta untuk kelompok umur yang sama yaitu 11; 12 dan $16,3 \mathrm{~mm}$. 


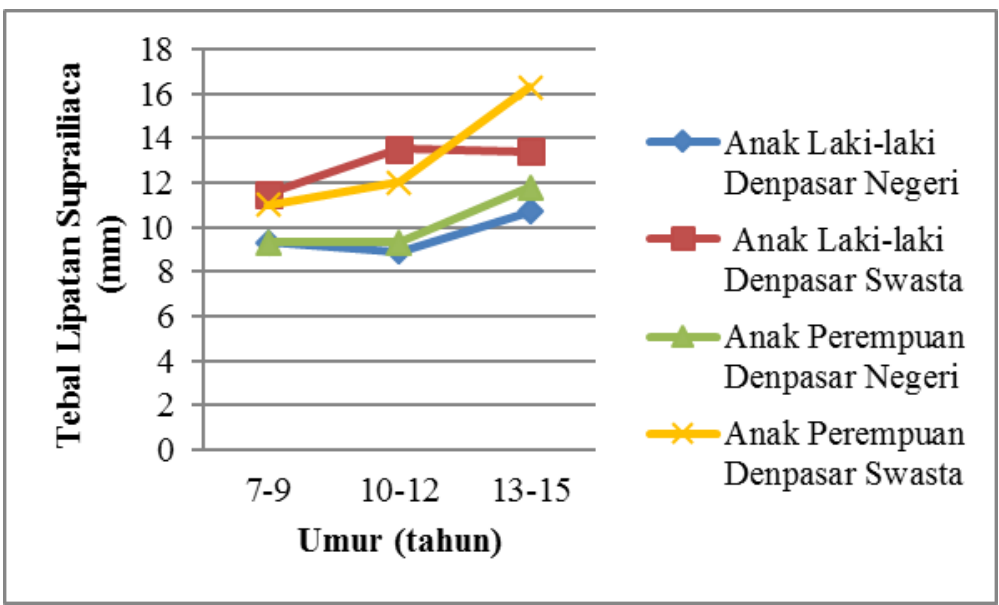

Gambar 5. Tebal lipatan kulit suprailiaca siswa-siswa sekolah swasta dan negeri Denpasar

\section{Indeks Massa Tubuh (IMT)}

Rerata indeks massa tubuh siswa di sekolah negeri di Denpasar untuk kelompok umur 7-9; 10-12 dan 13-15 lebih rendah dibandingkan siswa-siswa di sekolah swasta. Rerata pada siswa laki-laki di sekolah negeri berturut-turut 16,$5 ; 19$ dan $20 \mathrm{~kg} / \mathrm{m}^{2}$, sedangkan siswa laki-laki di sekolah swasta untuk kelompok umur 7-9; 10-12 dan 13-15 berturut-turut 18,2; 21,1 dan 20,1 $\mathrm{kg} / \mathrm{m}^{2}$. Siswa-siswa perempuan di sekolah negeri Denpasar untuk ukuran indeks massa tubuh pada kelompok umur yang sama yaitu 16,3; 17,6 dan 19,50 $\mathrm{kg} / \mathrm{m}^{2}$, sedangkan siswa perempuan di sekolah swasta untuk kelompok umur yang sama yaitu 18,1; 18,8 dan 20,4 $\mathrm{kg} / \mathrm{m}^{2}$.

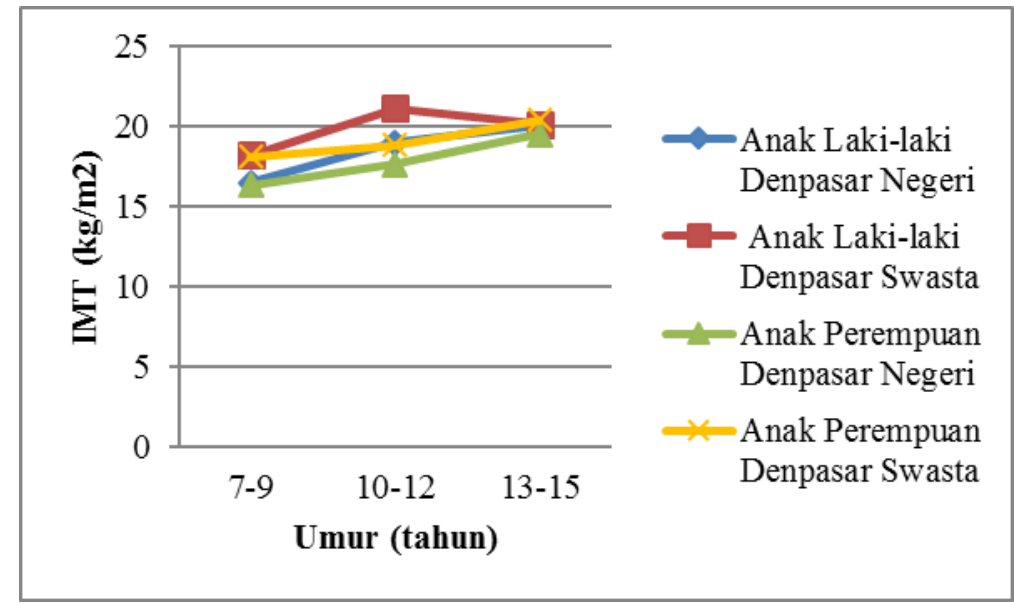

Gambar 6. Indeks massa tubuh siswa-siswa sekolah swasta dan negeri Denpasar

Hasil persentase kategori indeks massa tubuh menurut umur pada siswa laki-laki maupun perempuan dapat dilihat pada Gambar 7 dan Gambar 8. Hasil rerata menunjukkan siswa-siswa perempuan di sekolah swasta memiliki persentase kategori obese paling tinggi pada kelompok umur 7-9 tahun dibandingkan dengan siswa-siswa di sekolah negeri yang memiliki persentase kategori obese lebih rendah. 


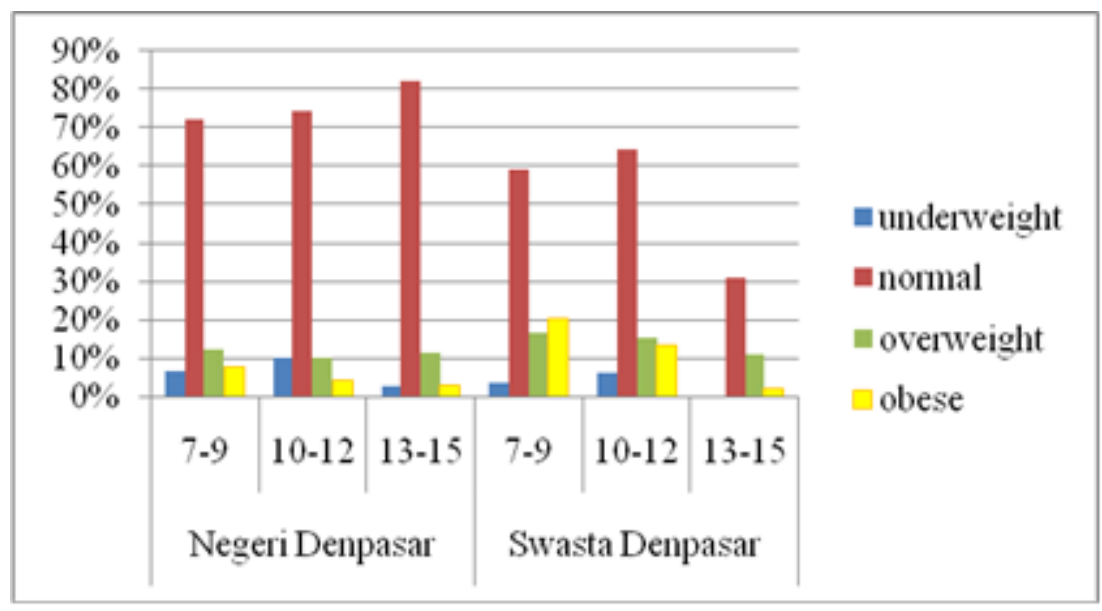

Gambar 7. Persentase kategori Indeks Massa Tubuh (IMT) siswa perempuan

Pada siswa laki-laki di sekolah swasta persentase kategori obese paling tinggi pada kelompok umur 10-12 tahun mencapai $31 \%$ sedangkan siswa-siswa di sekolah negeri dengan kategori obese paling tinggi hanya mencapai $16,3 \%$.

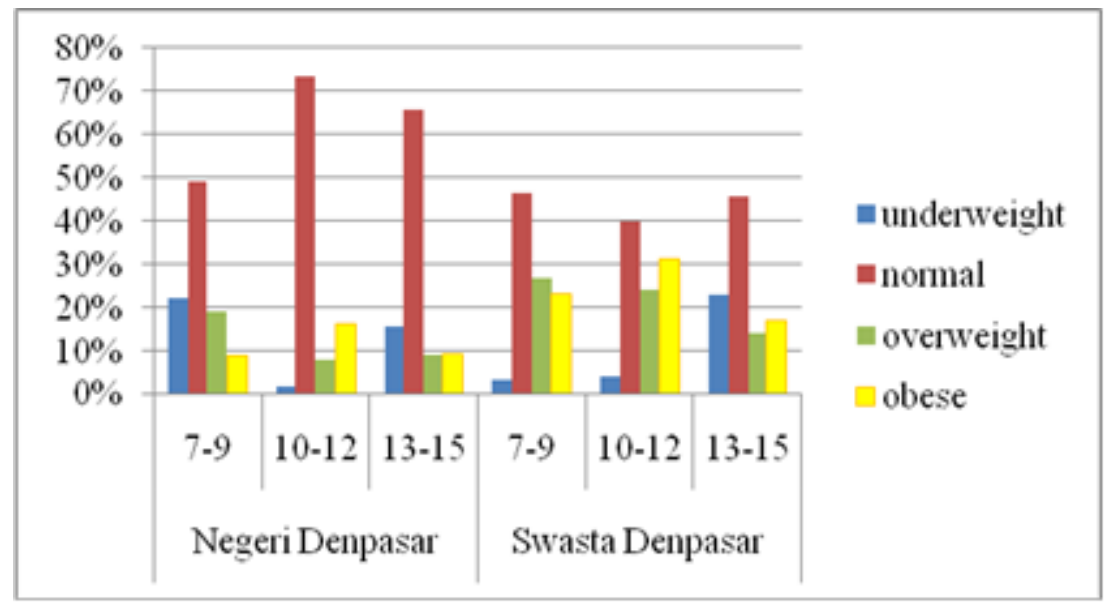

Gambar 8. Persentase kategori Indeks Massa Tubuh (IMT) siswa laki-laki

\section{Pendapatan orang tua}

Persentase pendapatan orang tua dari siswa sekolah dasar hingga sekolah menengah berbeda pada masing-masing sekolah negeri dan swasta di Denpasar. Persentase rata-rata pendapatan orang tua > Rp 2.000.000 pada seluruh kelompok umur di sekolah swasta mencapai 96,3\% sedangkan di sekolah negeri rata-rata pendapatan paling banyak pada kategori Rp 1.000.000- 2.000.000 mencapai 52,9\%. 


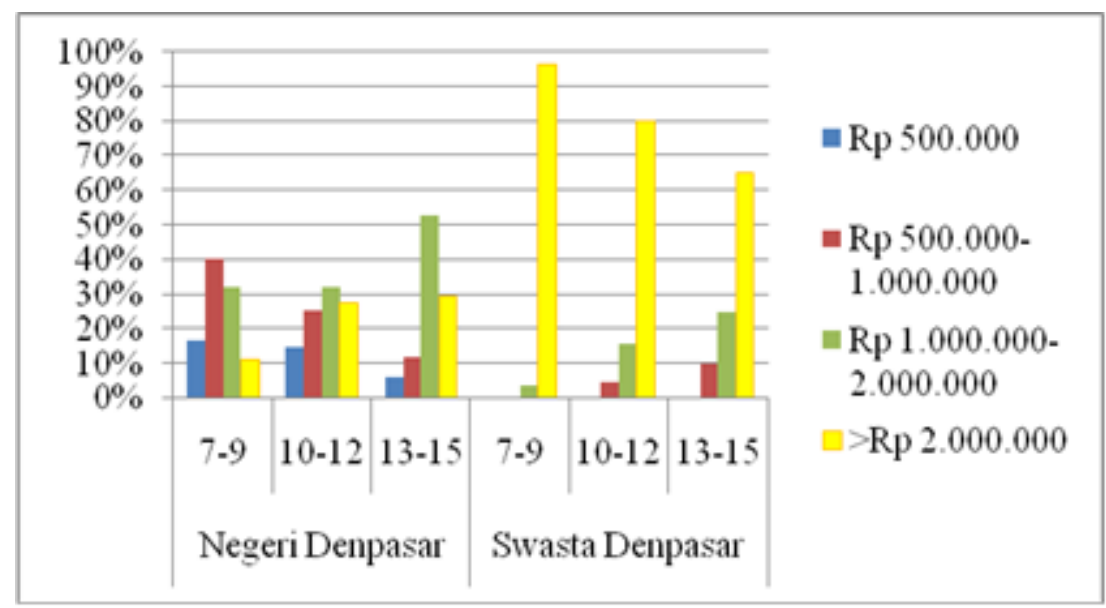

Gambar 9. Persentase pendapatan orang tua siswa di sekolah negeri dan swasta Denpasar

Pendapatan orang tua meningkatkan IMT siswa sekolah swata secara signifikan yang ditunjukkan oleh Uji Chi-Square dilakukan untuk mengetahui hubungan antara pendapatan orang tua dengan IMT pada masingmasing tempat penelitian (Tabel 2).

Tabel 2.Hasil uji Chi-Square IMT dan pendapatan orang tua pada seluruh populasi

\begin{tabular}{cc}
\hline IMT dengan Pendapatan Orangtua & Signifikansi $(<0,05)$ \\
\hline Negeri Denpasar & 0,08 \\
Swasta Denpasar & 0,01 \\
\hline
\end{tabular}

\section{Pola pertumbuhan siswa berdasarkan berat dan tinggi badan}

Pola pertumbuhan pada siswa laki-laki maupun perempuan dapat dilihat berdasarkan berat dan tinggi badan. Pada suatu populasi pola pertumbuhan dapat diprediksikan dengan melakukan pengukuran menggunakan metode antropometri terhadap individuindividu di dalamnya. Pola pertumbuhan dapat dijadikan referensi untuk menilai status kesehatan, gizi, obesitas dan resiko terhadap penyakit (Bogin, 1999).

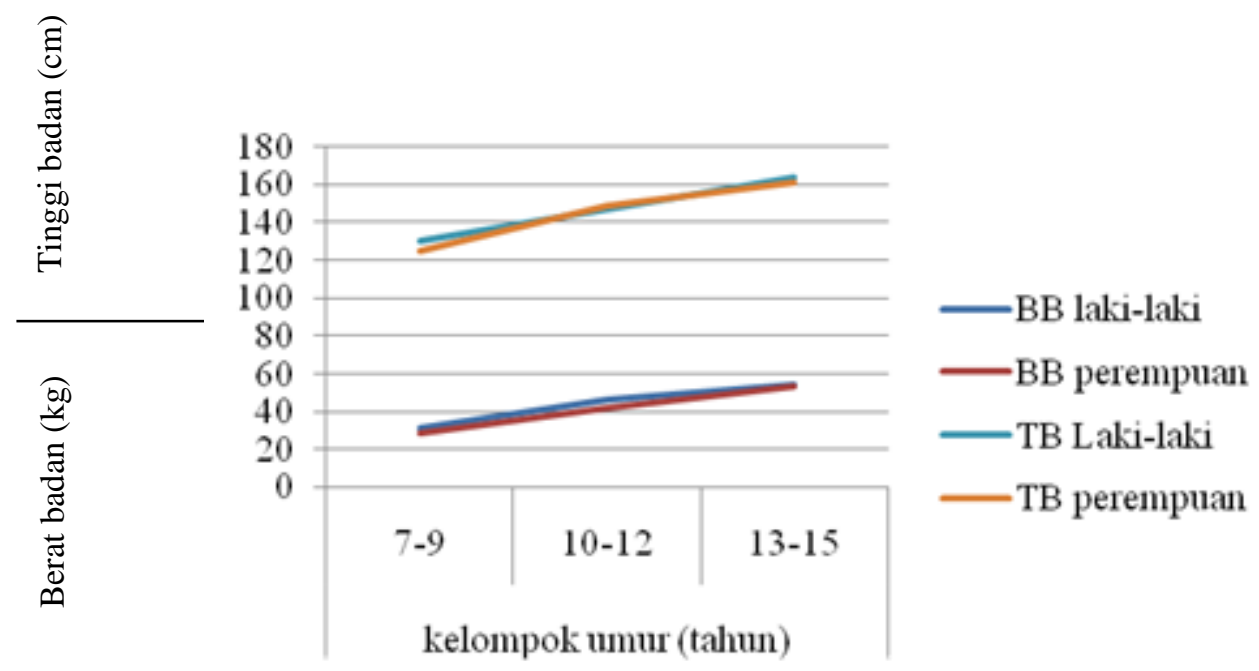

Gambar 10. Pola pertumbuhan siswa-siswa di sekolah negeri di Kota Denpasar 


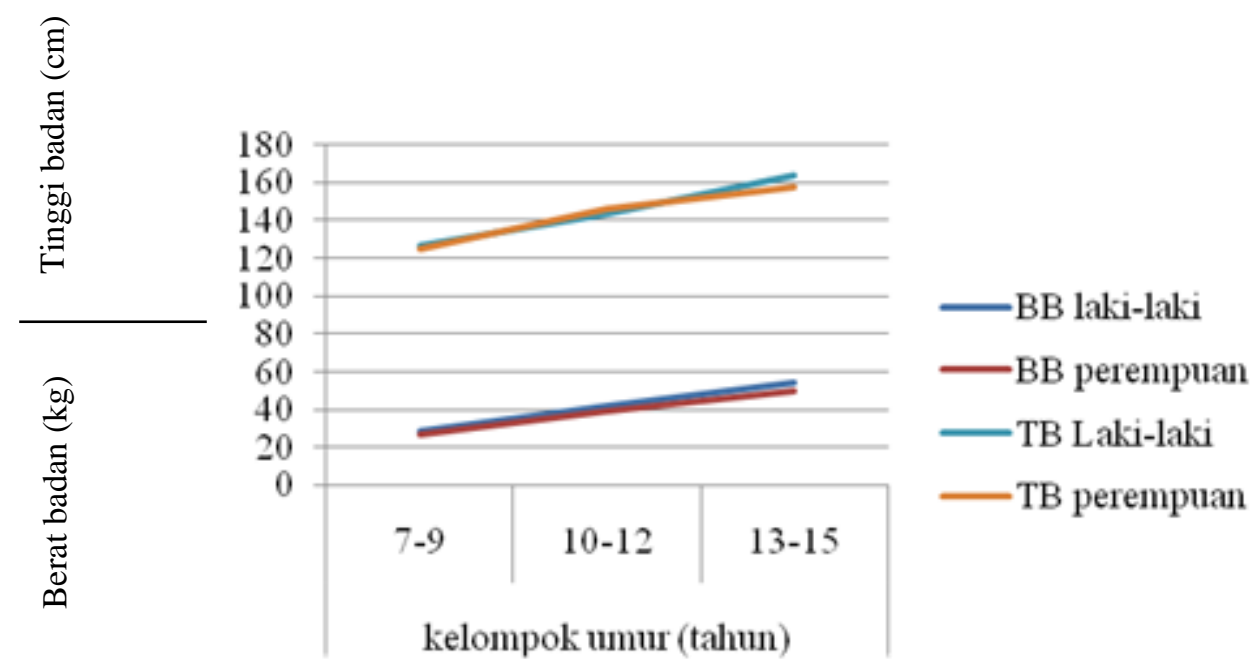

Gambar 11. Pola pertumbuhan siswa-siswa di sekolah swasta di Denpasar

\section{PEMBAHASAN}

Hasil pengukuran berat badan menunjukkan pola pertumbuhan berat badan pada siswa sekolah yaitu semakin bertambahnya umur, berat badan semakin meningkat. Pada penelitian ini siswa-siswa semua kelompok umur di sekolah negeri Denpasar memiliki rerata berat badan lebih rendah dibandingkan siswasiswa sekolah swasta. Hal ini kemungkinan disebabkan oleh frekuensi makan siswa-siswa sekolah swasta yang cukup tinggi. Dari hasil kuisioner data diri siswa-siswa sekolah swasta diketahui siswa-siswa tersebut memiliki frekuensi makan 4-5 kali sehari. Dari hasil wawancara, siswa-siswa di sekolah swasta hampir semua menkonsumsi makanan cepat saji. Selain itu, siswasiswa di sekolah swasta hampir semua melakukan sarapan pagi. Menurut Anzarkusuma et al. (2014), frekuensi makan berhubungan dengan status gizi siswa. Asupan gizi yang tidak seimbang akan mempengaruhi status gizi siswa. Kebiasaan makan berperan penting dalam menentukan tingkat status gizi siswa.

Pertumbuhan berat badan siswa laki-laki berhimpit dengan siswa perempuan disebabkan massa otot siswa laki-laki mengalami peningkatan. Oleh karena itu, siswa laki-laki memiliki massa otot yang lebih besar, sebaliknya siswa perempuan memiliki lemak subkutan yang lebih banyak saat masa pubertas. Periode keunggulan perempuan ini dapat diartikan sebagai peningkatan penimbunan lemak tubuh yang pesat saat pubertas (Bogin, 1999).

Pertumbuhan tinggi badan menunjukkan siswasiswa di sekolah negeri memiliki tinggi badan yang lebih rendah dibandingkan dengan siswa-siswa di sekolah swasta di Denpasar. Hal ini dapat dipengaruhi oleh faktor sosial ekonomi dan konsumsi makanan. Secara keseluruhan rerata tinggi badan siswa-siswa di sekolah negeri di Denpasar lebih rendah dibandingkan antara rerata tinggi badan siswa-siswa di sekolah swasta Denpasar. Hal ini kemungkinan dapat dipengaruhi oleh faktor sosial ekonomi dan konsumsi makanan. Menurut Weitz et al. (2000) perbedaan ukuran tinggi badan di tempat tinggal yang berbeda lebih dipengaruhi oleh faktor perbedaan nutrisi dan pertumbuhan sosial ekonomi. Pada penelitian yang dilakukan oleh Zong pada tahun 2010, menemukan bahwa di Cina pada siswa laki-laki maupun perempuan di daerah pedesaan rata-rata lebih pendek dibandingkan siswa-siswa di daerah pinggiran kota maupun di perkotaan (Zong et al., 2014).

Pertumbuhan tinggi badan siswa laki-laki di sekolah negeri maupun swasta Denpasar lebih besar dibandingkan tinggi badan siswa perempuan yang dimulai pada kelompok umur 7-9 tahun dan menjadi lebih rendah pada umur 10-15 tahun. Namun tinggi badan siswa laki-laki kembali meningkat dibandingkan dengan siswa perempuan pada kelompok umur 13-15 tahun. Perbedaan tinggi badan dapat disebabkan faktor genetik, lingkungan, asupan nutrisi dan status sosial ekonomi (Bogin, 1999). Rerata berat badan siswa laki-laki di sekolah negeri maupun swasta Denpasar lebih besar dibandingkan siswa perempuan pada umur 7-15 tahun. Pada penelitian Puspita (2004) menunjukkan pola pertumbuhan Siswa sekolahan di Bogor dimana pertumbuhan tinggi badan siswa laki-laki melaju secara konstan sampai usia 12 tahun dan kemudian meningkat sejak 13 tahun. Pada siswa perempuan tinggi badan meningkat menjelang menarche (menstruasi pertama kali, umumnya usia 12 tahun) dan melambat setelah menarche.

Siswa-siswa di sekolah negeri di Denpasar menunjukkan hasil pengukuran tebal lipatan kulit triceps, infrascapula dan suprailiaca lebih kecil dibandingkan siswa-siswa di sekolah swasta di Denpasar. Hal ini kemungkinan disebabkan oleh aktivitas fisik yang lebih 
tinggi sehingga lapisan lemak relatif lebih kecil (Hastuti, 2004). Pada siswa laki-laki kelompok umur 13-15 tahun di sekolah swasta mengalami penurunan dari kelompok umur sebelumnya. Berdasarkan wawancara langsung, beberapa siswa-siswa di sekolah swasta pada kelompok umur 13-15 tahun mengikuti olahraga fisik seperti fitnes dan sering mengikuti sepakbola dalam ruangan. Pada siswa perempuan kelompok umur 13-15 memiliki rerata tebal lipatan kulit suprailiaca yang tinggi. Hal ini dapat disebabkan oleh penyebaran lemak yang timbul sejak pubertas dan biasanya tersebar di bagian payudara, perut bagian bawah, paha dan sekitar alat genital (Bannister et al., 1995). Selain itu dapat disebabkan karena periode keunggulan perempuan, dimana pada saat pubertas siswa perempuan mengalami peningkatan distribusi lemak tubuh di pinggul, bokong dan paha (Bogin, 1999).

Siswa-siswa di sekolah swasta memiliki persentase kategori obese tertinggi dibandingkan dengan negeri di Denpasar. Penelitian Kamelia (1999) di kota Medan menunjukkan siswa-siswa di sekolah swasta memiliki kejadian obesitas lebih tinggi dibandingkan siswasiswa di sekolah negeri. Pada penelitian ini kecenderungan obese tertinggi adalah pada siswa lakilaki. Pada penelitian Sartika (2011) menunjukkan siswa laki-laki memiliki risiko obesitas lebih tinggi dibandingkan siswa perempuan.Penelitian Ariani (2007) juga menyebutkan siswa laki-laki memiliki kecenderungan obesitas lebih tinggi dibandingkan siswa-siswa perempuan di Medan.

Tingginya persentase obesitas pada sekolah swasta di Kota Denpasar kemungkinan disebabkan karena adanya hubungan IMT dengan faktor ekonomi orang tua siswa. Uji chi-square menunjukkan hasil signifikan $<0,05$ antara pendapatan orang tua dengan IMT. Berdasarkan persentase pendapatan orang tua di sekolah swasta menunjukkan pesentase mencapai 96,3\% dengan pendapatan lebih dari Rp. 2.000.00o dan tidak terdapat orang tua dengan pendapatan Rp. 500.000. Tingkat pendapatan orang tua mempunyai pengaruh terhadap status gizi siswa baik berdasarkan berat badan maupun tinggi badan (Astuti dan Irdawati, 2011). Kemampuan keluarga untuk membeli bahan makanan antara lain tergantung pada besar kecilnya pendapatan keluarga. Keluarga dengan pendapatan terbatas kemungkinan besar akan kurang dapat memenuhi kebutuhan makanannya terutama untuk memenuhi kebutuhan zat gizi dalam tubuhnya (Waruwu, 2002). Pada penelitian Widiyani et al. (2011) menunjukkan bahwa pendapatan bulanan dari orang tua adalah prediktor utama yang mempengaruhi lemak tubuh.

Keadaan 'obese' pada siswa dapat menjadi faktor resiko yang signifikan untuk mengalami obesitas di masa dewasa. Obesitas merupakan penyakit yang kompleks karena diantaranya terkait faktor hereditas, pilihan makanan, aktivitas fisik, pengaruh media, sensasi rasa, ketersediaan tempat untuk berolahraga dan pengaruh keluarga serta sosial (Sartika,2011). Selain itu, obesitas dapat disebabkan karena asupan makan yang berlebihan. Hasil penelitian Hidayati et al. (2006) menunjukkan bahwa peningkatan asupan karbohidrat akan meningkatkan kadar kolesterol total. Pada umumnya di negara yang sedang berkembang karbohidrat merupakan sumber energi utama. Karbohidrat merupakan bahan dasar pembentukan trigliserida sehingga kelebihan asupan karbohidrat akan disimpan dalam bentuk lemak di bawah kulit. Bila asupan karbohidrat yang berlebihan ini berlangsung lama akibatnya terjadi obesitas yang berkaitan erat dengan peningkatan kadar trigliserida. Hal ini sesuai dengan kondisi di Indonesia yang mempunyai sumber energi utama karbohidrat sehingga dapat menjelaskan mengapa semua subjek mempunyai kadar trigliserida yang tinggi (Waspadji, 2003).

Kemajuan teknologi seperti adanya kendaraan bermotor dan fasilitas yang mempermudah lainnya dapat memicu terjadinya obesitas karena kurangnya aktivitas fisik yang dilakukan oleh seseorang. Hal tersebut sesuai dengan hasil wawancara terhadap probandus yang hampir seluruh probandus diantar jemput oleh orangtua. Selain aktivitas tersebut, konsumsi makanan yang tidak terkontrol juga dapat mempengaruhi obesitas. Mengonsumsi makanan junk food juga dapat menyebabkan obesitas karena pada umumnya berkalori tinggi (Allo et al. , 2013).

Remaja dengan kondisi sosial ekonomi orang tua yang lebih baik yang bersekolah pada sekolah yang berada di pusat kota yang penuh dengan segala fasilitas pertokoan yang menyediakan fastfood juga fasilitas untuk mengakses informasi seperti tempat akses internet memungkinkan remaja mempunyai status kesehatan dan nutrisi yang lebih baik serta paparan informasi yang lebih terbuka (Astuti dan Irdawati, 2011). Pada penelitian Oktaviani (2012) kebiasaan konsumsi fast food berhubungan dengan indeks massa tubuh siswa.Selain itu penelitian Allo et al. (2013) menyebutkan terdapat hubungan yang bermakna antara kebiasaan konsumsi fast food dengan kejadian gizi lebih pada siswa SD Negeri Sudirman I Makasar. Penelitian Padmiari (2002) yang dilakukan di Kota Denpasar menunjukkan semakin banyak jenis fast food yang dikonsumsi dan semakin besar jumlah kalorilfast food yang dikonsumsi maka semakin tinggi kejadian obesitas pada siswa-siswa. Pola makan siswa sangat berkaitan erat dengan gizi lebih karena semakin sering siswa menkonsumsi makanan dalam sehari maka kecenderungan untuk mengalami gizi lebih sangat tinggi. Dari hasil pengamatan di sekolah terdapat beberapa contoh makanan junk food yang dikonsumsi siswa-siswa saat pulang sekolah yaitu pentol rebusan (cilok), tempura goreng, ayam goreng tepung dan jajanan pinggir jalan lainnya. 
Peningkatan status gizi dalam masyarakat berkaitan dengan permasalahan status sosial ekonomi. Masalah gizi muncul akibat masalah ketahanan pangan ditingkat rumah tangga yaitu kemampuan rumah tangga memperoleh makanan untuk semua anggota sehingga masalah gizi tidak lagi masalah kesehatan tetapi juga masalah kemiskinan, pemerataan dan masalah kesempatan kerja (Supariasa et al., 2002). Faktor sosial ekonomi orang tua merupakan salah satu faktor yang mengakibatkan status gizi karena mempengaruhi penyediaan makanan sehari-hari termasuk menu dan jumlahnya. Status sosial ekonomi keluarga bersama faktor lainnya

\section{KEPUSTAKAAN}

Anzarkusuma, I.S., E.Y. Mulyani, I. Jus'at, D. Angkasa. 2014. Status Gizi Berdasarkan Pola Makan Siswa Sekolah Dasar di Kecamatan Rajeg,Tangerang. Ind. J. Hum.Nutri. (1) 2: 135-148.

Ariani, A. dan T. Sembiring.2007. Prevalensi Obesitas pada Siswa Sekolah Dasar DI Kota Medan.Maj. Ked. Nus.40(2) :86-89.

Artaria, M. D., 2008. Perbedaan antara Laki-laki dan Perempuan : Penelitian Antropometris pada Siswasiswa Umur 6-19 Tahun. J. Masy.Kebud. Pol. 27(6): 561-569.

Astuti, R.K. dan Irdawati. 2011. Hubungan Antara Status Sosial Ekonomi Keluarga dengan Status Gizi Siswa Usia Sekolah di SDN Godog I Polokarto Sukoharjo(Tesis). Surakarta.

Bannister, L.H., M. Berry., P. Collins. 1995. Gray's Anatomy. Thirty-eight ed. Churchil Livingston, New York.

Bogin, B. 1999. Patterns of Human Growth. Edisi ke-2. New York: Cambridge University Press.

Centers for Disease Control and Prevention. 2015 .National Center for Health Statistics in collaboration with the National Center for Chronic Disease Prevention and Health Promotion http://www.cdc.gov/growthcharts

Hasmyati dan Ians Aprilo.2014. Analisis Pengukuran Fore metric dan Myoline Atlet PPLM Universitas Negeri Makassar. J. Cakr. Pend.(33)2: 315-323.

Hastuti, J. 2004. Ciri-Ciri Antropometri dan Kapasitas Vital Penduduk di Dataran Tinggi Samigaluh dan Dataran Rendah Galur Kabupaten Kulon Progo Daerah Istimewa Yogyakarta (Tesis).Yogyakarta. 2007. Physical Status and Motoric Performance of Junior High School Children Age of 12-15 years in Rural and Urban Bantul Yogyakarta. J. Med. Scie. (Berkala Ilmu Kedokteran) 39(4):162-176.

Hidayati, S.N., H. Hadi dan W. Lestariana. 2006. Hubungan Asupan Zat Gizi dan Indeks Massa Tubuh dengan Hiperlipidemia pada Murid SLTP yang Obesitas di Yogyakarta. Sari Pediatri 8(1): 25-31.

Kamelia, E. 1999. Kejadian Obesitas pada Siswa Usia 1013 tahun di Tiga Sekolah Dasar Negeri dan Tiga seperti kondisi perumahan dan sanitasi yang buruk, tidak tersedianya air bersih serta adanya penyakit infeksi akan mempengaruhi pertumbuhan siswa (Latif, 2000).

\section{SIMPULAN}

Pola pertumbuhan siswa laki-laki maupun perempuan di sekolah negeri lebih rendah dibandingkan siswa laki-laki maupun perempuan di sekolah swasta Denpasar. Pendapatan orang tua mempengaruhi pola pertumbuhan berat dan tinggi badan siswa-siswa.

Sekolah Dasar Swasta Kotamadya Medan (Tesis). Medan.

Latief, A. 2000.Diagnosis fisik pada Siswa. Penerbit Sagung Seto: Jakarta.

Oktaviani W.D. 2012. Hubungan Kebiasaan Konsumsi Fast Food, Aktivitas Fisik, Pola Konsumsi, Karakteristik Remaja Dan Orang Tua Dengan Indeks Massa Tubuh (IMT). J. Kes.Masy.1(7):2-3.

Padmiari, I.A.E. 2002.Prevalensi Obesitas dan Konsumsi Fast Food sebagai Faktor Resiko Terjadinya Obesitas pada Siswa SD di Kota Denpasar (Tesis).Yogyakarta.

Purbaningsih, M., A. Chusida., dan B. Soegeng. 2011. Penentuan Usia Growth Spurt Pubertal Mandibula Perempuan Berdasarkan Cervical Vertebral Maturation Indicators (IMIs). J.PDGI 6o(1): 15-19.

Sartika, R. A. D. 2011. Faktor Risiko Obesitas pada Siswa 5-15 Tahun di Indonesia. MAK., KES. 15(1): 37-43.

Supariasa, I.D.N., B. Bakri dan I. Fajar. 2002. Penilaian Status Gizi.EGC. Jakarta.

Waruwu, F.2002. Perbedaan Sosial Ekonomi dan Budaya.[Online], Available:“ http://aising.uum.edu my/research/e-thesis/sc.sosial”.

Waspadji, S. 2003. Asupan Zat Gizi dan Beberapa Zat Gizi pada Penderita Hiperlipidemia dalam Pengkajian Status Gizi Studi Epidemiologi. Balai Penerbit FKUI.

Weitz, C.A., C. Chin, R. M. Garruto, X. He, J. Liu, R. Liu.2000. Morphological growth of Han Boys and Girls Born and Raised Near Sea Level and At High Altitude in Western China. Am. J.Human Biol. 12.

Widiyani, T., B. Suryobroto., S. Budiarti., dan A. Hartana. 2011. The Growth of Body Size and Somatotype of Javanese Children Age 4 to 20 Years. HAYATI J. Biosc. 18(4): 182-192.

Zong, Xin-Nan and Li-Hui. 2014. Physical Growth of Children and Adolescents In China Over the Past 35 years. World Health Organization.Bulletin of the World Health Organization. p.55-64. 